\title{
Morphological range of hyperplastic polyps and carcinomas arising in hyperplastic polyps of the stomach
}

\author{
T HATTORI
}

From the Department of Pathology, Fukui Medical School, Matsuoka Yoshida-gun Fukui, 910-11 Japan

SUMMARY A morphological range of 67 hyperplastic polyps was studied. They included polyps removed endoscopically and polyps found incidentally in resected stomachs with gastric ulcers and cancer. The hyperplastic polyps were essentially composed of cystic foveolae and pyloric type glands, lined by cells identical to those of the normal gastric mucosa. Thirty one polyps contained other cytological elements. In 18, intestinal metaplasia was seen; the tubules were mostly composed of columnar and goblet cells and lacked Paneth cells. In 11 polyps, nine cases of gastric dysplasia and two cases of intestinal dysplasia, dysplastic changes were found. The former consisted of a proliferation of irregularly shaped pits with pleomorphic cuboidal/columnar cells with relatively basophilic cytoplasm. They contained mucigen granules of a gastric type. The latter consisted of atypical pits composed of closely packed, tall columnar and small goblet cells, both resembling adenomatous cells of the colon. In three polyps carcinomas were seen, one of which was an intestinal type adenocarcinoma. In the other two, the cancer cells closely resembled the normal foveolar cells, containing gastric type mucigen granules. They were gastric type adenocarcinomas.

The malignant potential of epithelial polyps of the stomach continues to be a subject of considerable discussion.' According to the recent classification, two main types of polyp are distinguished: adenomatous and hyperplastic polyps. ${ }^{1-8}$ Adenomatous polyps are usually antral and are mostly sessile. ${ }^{2}$ They are composed of atypical, intestinal type cells not normally present in the stomach. The terms intestinal dysplasiay or borderline lesion ${ }^{10} " 1$ are used synonymously. In these polyps striking epithelial atypias and even changes indistinguishable from malignancy are occasionally seen. Not infrequently they coexist with gastric cancers. ${ }^{11-13}$ Adenomatous polyps have been thus considered to be premalignant.

Hyperplastic polyps are more common. ${ }^{14}$ They consist of branching, cystically dilated glandular tubules lined by cells identical to those of the normal gastric mucosa. Cellular and nuclear atypias are not usually seen in these polyps, ${ }^{14}$ which suggests that they may be harmless. Gastric carcinomas are sometimes found in stomachs with hyperplastic polyps, ${ }^{45}$

Accepted for publication 22 January 1985 however, and carcinomas occasionally arise in polyps other than adenomas. ${ }^{45}$ Hyperplastic polyps must therefore have some malignant potential. The aim of the present study was to define a morphological range of hyperplastic polyps and show how they may be related to the development of gastric carcinoma.

\section{Material and methods}

This study was based on polyps removed endoscopically and polyps found incidentally in resected stomachs with gastric cancer and ulcers. From a total of 58 endoscopically removed polyps and 189 resected stomachs documented between 1978 and 1984, we selected 67 acceptable as hyperplastic polyps. Other polypoid lesions, which included villous adenomas, adenomatous polyps of IIa subtype, ${ }^{11}$ inflammatory fibroid polyps, and non-epithelial tumours were not studied.

In 67 polyps studied there were some mixed forms of hyperplastic polyp, adenomatous polyp, or carcinoma. These polypoid lesions were studied when part of the hyperplastic polyp was large enough to 


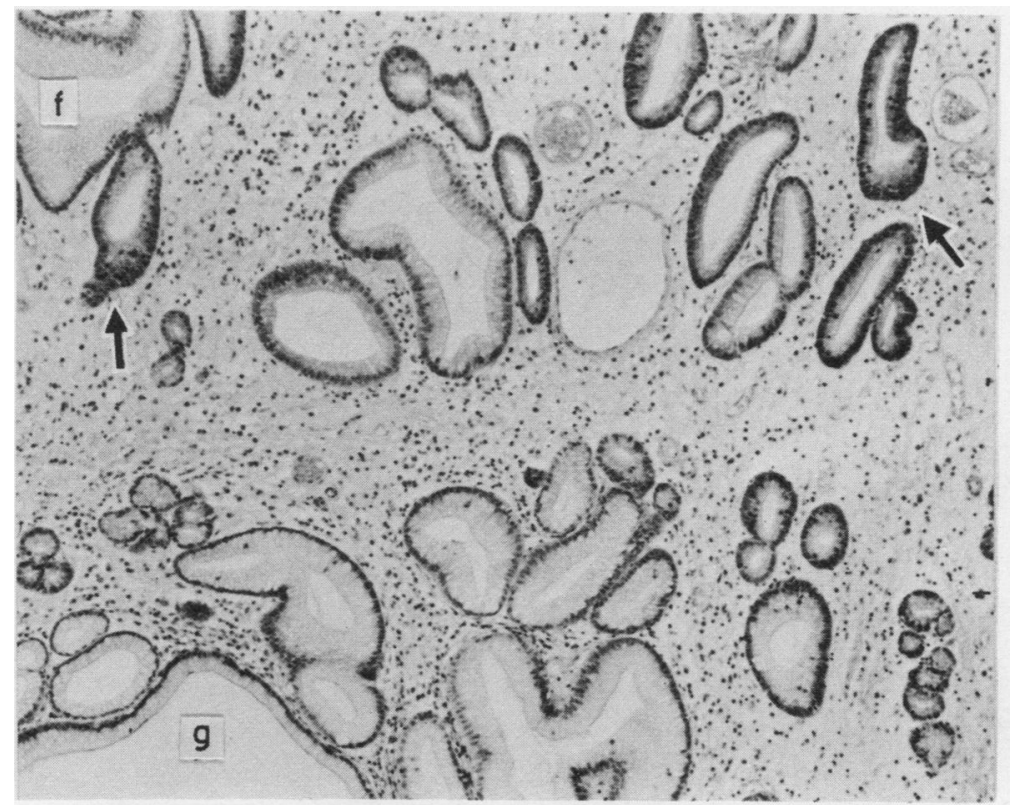

Fig. 1 Typical hyperplastic polyp. The polyp consists of elongated foveolae $(f)$ and mucinous glands of a pyloric type (g). Between the foveolae and glands, a zone of mitotic cells is seen (arrows). $\times 100$

be considered representative of the original lesion.

Most specimens were fixed in $10 \%$ formalin for 24-48 $\mathrm{h}$ and embedded in paraffin; they were serially cut. In addition to routine haematoxylin and eosin and periodic acid Schiff staining (oxidised by $44 \mathrm{mM}$ periodic acid at $37^{\circ} \mathrm{C}$ and by $0.1 \mathrm{mM}$ periodic acid at $0^{\circ} \mathrm{C}$ ), we applied mucin staining with alcian blue at $\mathrm{pH} 1.0$ and $2.5^{14}$ and with high iron diamine. ${ }^{1516}$ With these mucin stainings we differentiated gastric type mucin from intestinal type mucin.

Some material was fixed in $4 \%$ glutaraldehyde for $20 \mathrm{~min}$ and then postfixed in $1 \%$ osmium tetroxide for $2 \mathrm{~h}$. This material was embedded in epon 812 . The cases for electron microscopical study were selected by examining the biopsy specimens, which were taken before polypectomy or operation. We had to study some special cases, however, with the material fixed in $10 \%$ formalin. This was postfixed in $1 \%$ osmium tetroxide for $4 \mathrm{~h}$ and embedded in epon 812. Ultrathin sections were then studied with a HITACHI H-600 electron microscope.

\section{Results}

A series of hyperplastic polyps was obtained from patients of both sexes, ranging in age from 26 to 68 years. The largest polyp was about $2.2 \mathrm{~cm}$ in diameter, and the smallest one measured $0.4 \mathrm{~cm}$. Diam- eters of most polyps ranged between 0.6 and 1.6 $\mathrm{cm}$. The histological findings are given below; there was no correlation between histological characteristics and age and sex of patients.

\section{NORMAL HYPERPLASTIC POLYP AND \\ REGENERATIVE ATYPIA}

Sixty seven polyps were examined: 36 were typical hyperplastic polyps. They were characterised by an irregular broadened contour of pits (Fig. 1). The elongated pits communicated with glands composed of mucinous cells of a pyloric type. Between the foveolae and glands there was an immature cell population with scant, basophilic cytoplasm. Mitotic cells were confined to this region. The epithelial cells lining the upper foveolae were strikingly cylindrical. The nuclei were situated in the basal cytoplasm, and the apical cytoplasm was filled with neutral mucin, which stained with periodic acid Schiff, but not with alcian blue or high iron diamine. ${ }^{16}$ Ultrastructurally, the foveolar cells of the polyps were identical to their counterparts. ${ }^{17}$ They contained variously sized, stippled mucigen granules of relatively low electron density.

Some polyps contained atypical cells near areas of the surface erosion (Fig. 2). This change was referred to as regenerative atypia. The atypical cells with basophilic cytoplasm and irregularly shaped nuclei 


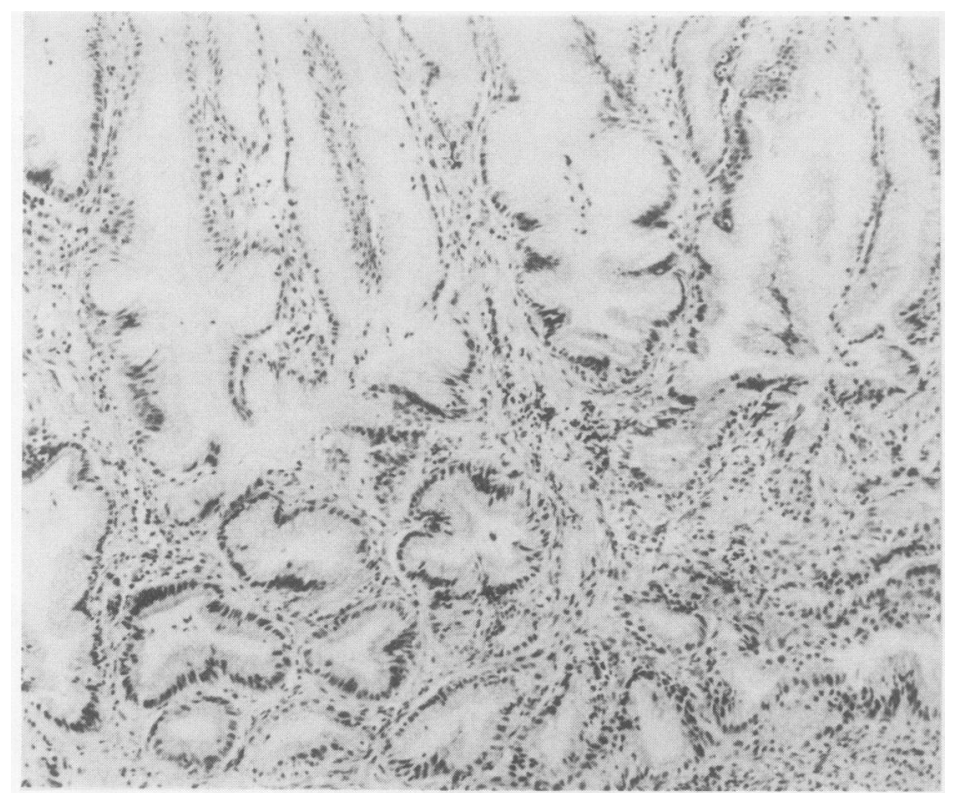

Fig. 2 Regenerative atypia. Atypical basophilic cells are found in deep parts of foveolae. $\times 100$

were confined to the region between the pits and glands.

\section{INTESTINAL METAPLASIA AND EOSINOPHILIC VARIANT}

Eighteen polyps (ages of patients 43 to 68 years) contained intestinal cells. Columnar and goblet cells were commonly found (Fig. 3), though a brush border was poorly developed. Intestinal metaplasia was mostly of an incomplete type..$^{18}$ Complete metaplasia with Paneth cells was found in only 5\% (3/67) of the polyps.

Spatially, the intestinal cells were found only sporadically inside the polyps. By contrast, antral mucosa outside the polyps studied showed striking metaplasia and was usually of a complete type. ${ }^{18}$ The incidence of metaplasia in the antral mucosa was about $60 \%$ in patients over 40 .

Five polyps (ages of patients 45 to 62 years) contained peculiar ducts, composed of eosinophilic columnar cells (Fig. 4). The cell boundaries were not clear. The cells occasionally had large oval nuclei, which contained one or two distinct nucleoli. This lesion seemed to be identical to those described by Muto and Oota ${ }^{14}$ as eosinophilic ducts (Fig. 4).

\section{DYSPLASIAS}

\section{Gastric dysplasia}

In nine polyps (patients ages 38 to 53 years) an atypical proliferation of the pits composed of gastric type cells was seen. The pits were irregularly shaped and the cells had relatively basophilic cytoplasm (Figs. 5 and 6). Their nuclei were pleomorphic. These pits sometimes communicated with pyloric type glands, but they were often elongated deep in the polyp. Cellularity was occasionally high, resulting in an intraluminal papillary growth of the pits, and piling up of the nuclei was often seen. Mitoses were widely distributed in the cells of the pits. There was a range of cytological abnormalities from mild to severe dysplasia (Figs. 5 and 6). Some focal lesions were so highly cellular and pleomorphic that they might be considered malignant. The dysplastic cells of this category resembled the normal foveolar cells; they had well developed endoplasmic reticulum and abundant ribosomes. They contained coarsely stippled mucigen granules of a surface mucous cell type. Their mucin was neutral, stained with periodic acid Schiff, but did not stain with alcian blue and high iron diamine.

\section{Intestinal dysplasia}

In two polyps (from a 53 year old man and a 62 year old woman) intestinal dysplasia was found (Fig. 7). The epithelium consisted of densely packed glandular tubules, composed of darkly stained columnar cells with elongated nuclei and small goblet cells. Mitotic cells were often seen. The lesion resembled the adenomatous polyp of the colon. Dysplastic cells were mostly found at the upper parts of the polyps. Mucin droplets of goblet cells and surface coat 


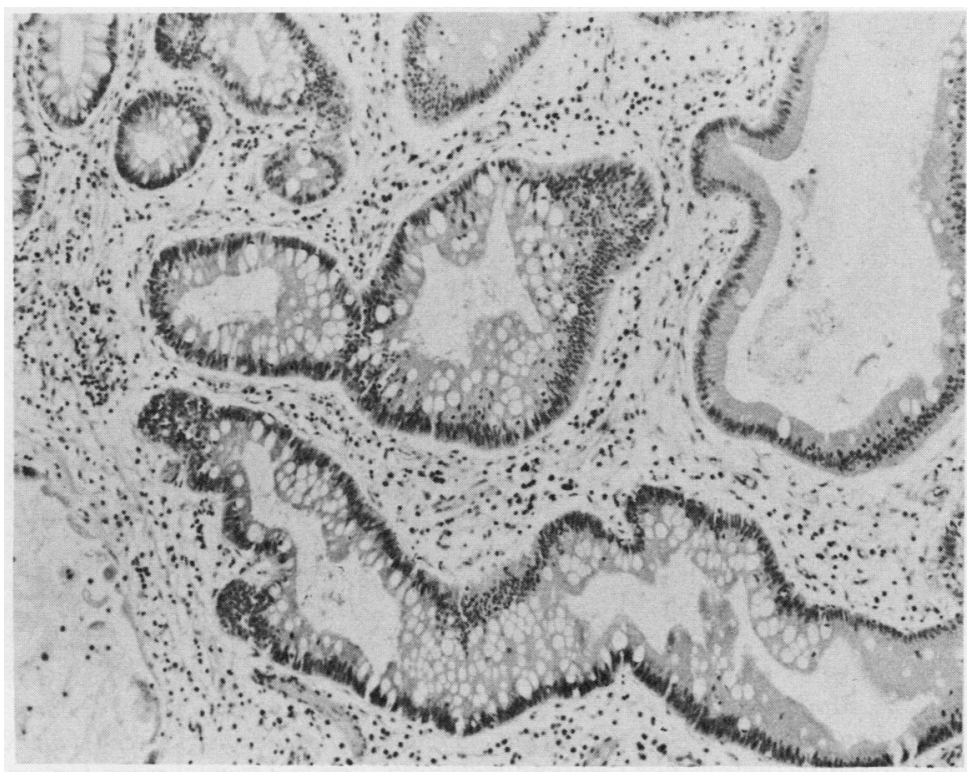

Fig. 3 Intestinal metaplasia. The tubules consist of columnar and goblet cells.

Paneth cells are not seen. $\times 100$

mucin were sulphomucin and stained with periodic acid Schiff, alcian blue, and high iron diamine.

\section{Indefinite dysplasia}

Seventeen polyps (patients' ages 33 to 58 years) contained abnormal foveolae, with large cells distended with mucin (Fig. 8). They resembled intestinal goblet cells but were much larger. Their mucin droplets were not homogenous but vacuolated, and multiloculated. Histochemically, the mucin was of a

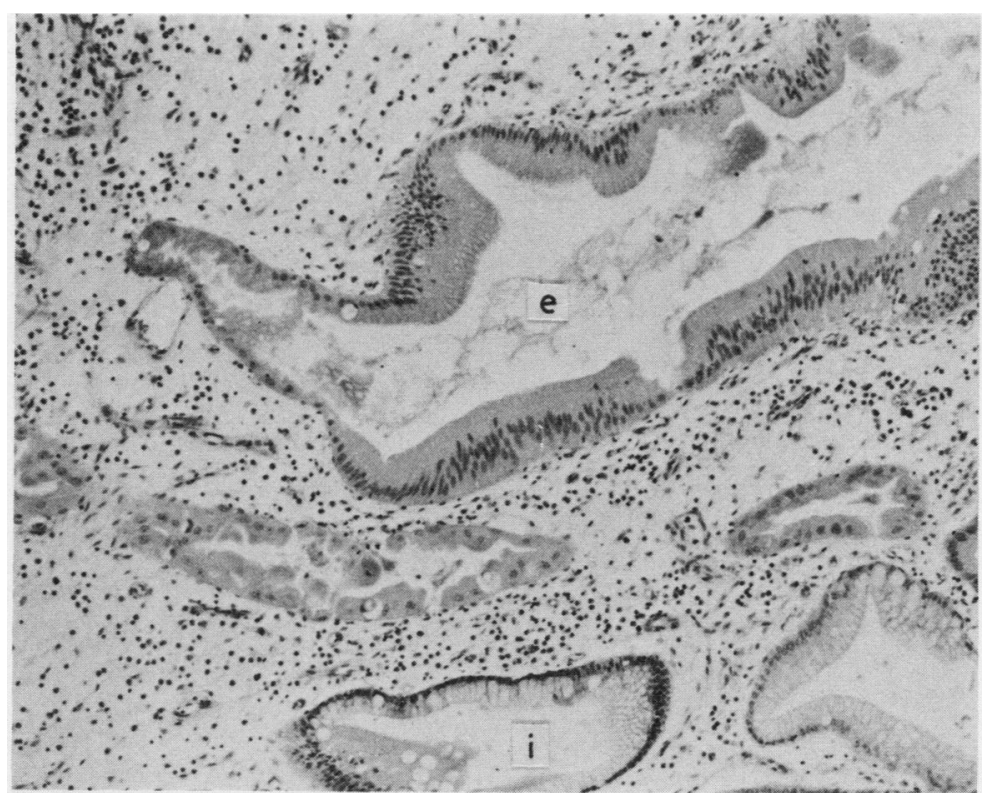

Fig. 4 Eosinophilic duct (e). Small goblet cells are seen. The cell boundaries are not clear. $i$ marks a metaplastic tubule. $\times 100$ 


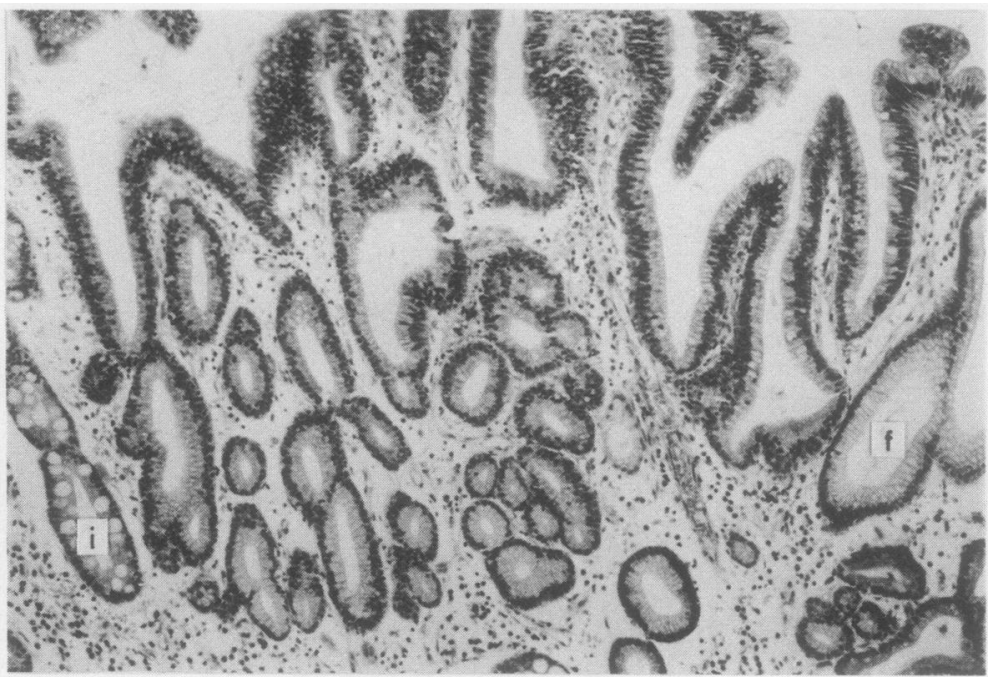

Fig. 5 Moderate dysplasia of a gastric type. The pits are composed of atypical basophilic cells. Their nuclei are round, and piling up of the nuclei is seen. fmarks a non-dysplastic foveola and $i$ marks a metaplastic tubule. Original magnification $\times 100$.

gastric type, stained with periodic acid Schiff, but did not stain with alcian blue and high iron diamine. Mitotic cells were not found in this group of cells, and the change might reflect abnormal differentiation of surface mucous cells rather than dysplasia.

\section{ADENOCARCINOMAS}

Gastric cell type adenocarcinoma

In two polyps (from a 45 year old woman and a 52 year old man), a foveolar cell type adenocarcinoma

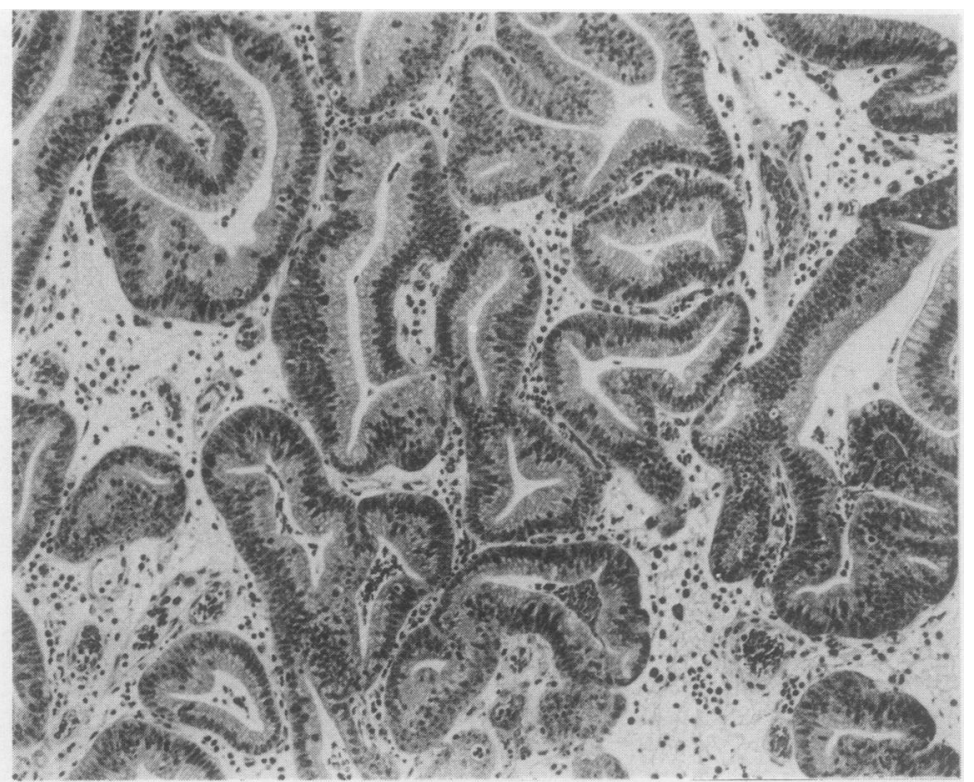

Fig. 6 Severe dysplasia of a gastric type. The pits are tortuous, the cellularity is high, and nuclear pleomorphism is seen. Mitotic cells are commonly seen. $\times 100$ 


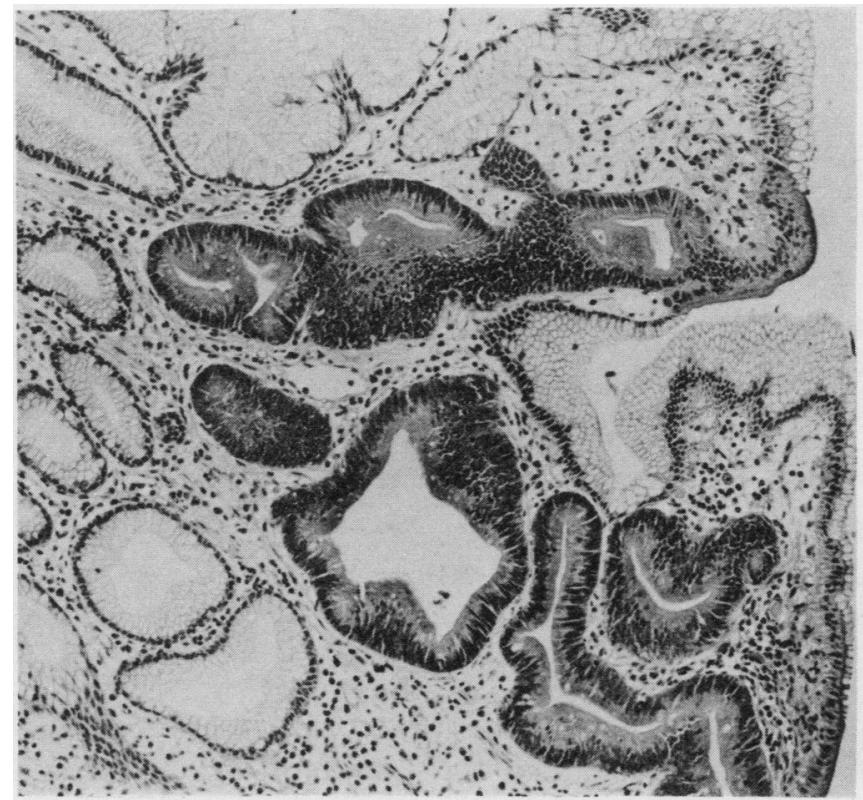

Fig. 7 Intestinal dysplasia. Several tubules are composed of basophilic columnar cells and small goblet cells, both resembling adenomatous cells in the colon. $\times 100$

was seen (Fig. 9). The cancers consisted of tortuously proliferated pits. The intraluminal papillary growth was prominent, resulting in an irregular budding of the pits. The cancer cells were tall col- umnar cells, resembling the normal foveolar cells. Their nuclei were round and situated in the basal cytoplasm. The cells had one or two large nucleoli. Mitotic cells were commonly found and were distri-

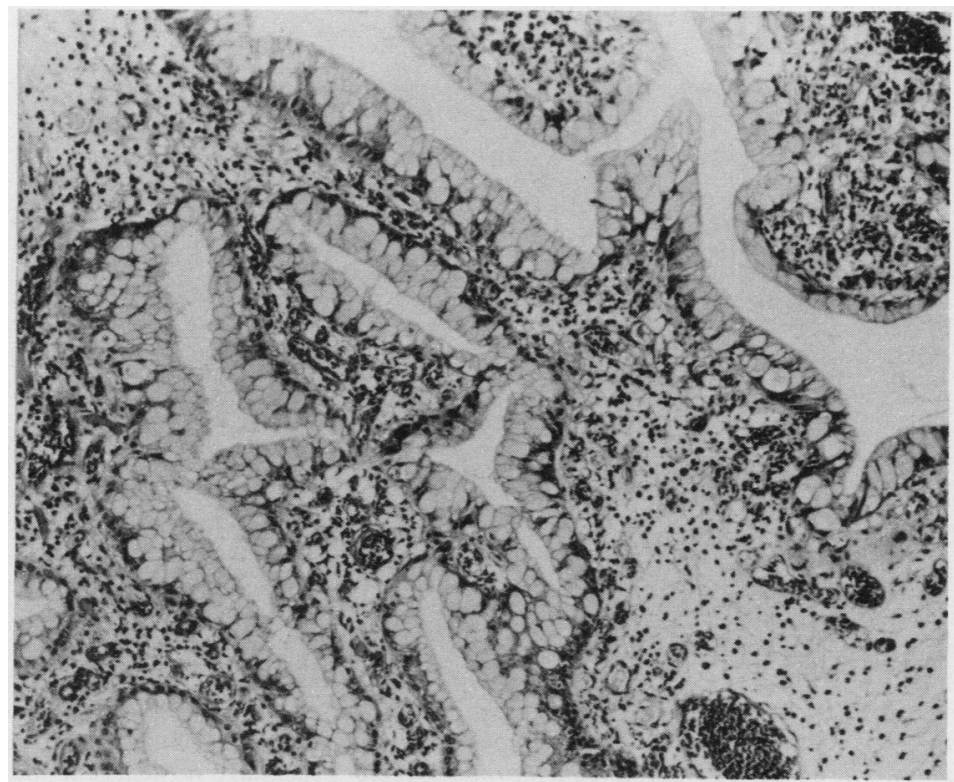

Fig. 8 Abnormal differentiation of the foveolar cells. The cells contained large mucin droplets in the apical cytoplasm. $\times 100$ 


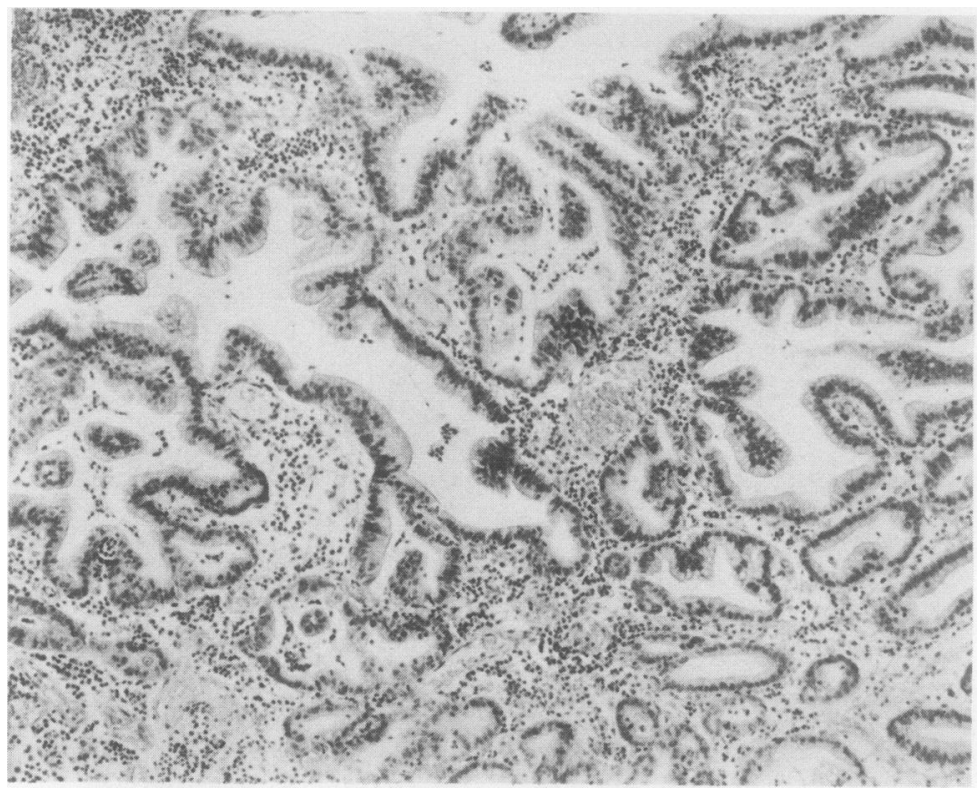

Fig. 9 Gastric type adenocarcinoma. The tubules are variously sized. The cancer cells closely resemble the normal foveolar cells. $\times 100$

buted throughout the tissue. Mucin droplets were seen in the apical cytoplasm, which consisted of neutral mucin which stained with periodic acid Schiff but not with alcian blue and high iron diamine (Fig. 10). The surface coat mucin was also of a gastric type. Ultrastructurally, the cancer cells were well polarised and had well developed endo- plasmic reticulum around the nucleus. A few microvilli were seen at the luminal surface. The lateral surface was interdigitated. Most of the cancer cells contained stippled mucigen granules of low electron density (Fig. 11). The cancer was thus considered to be of a gastric foveolar cell type.

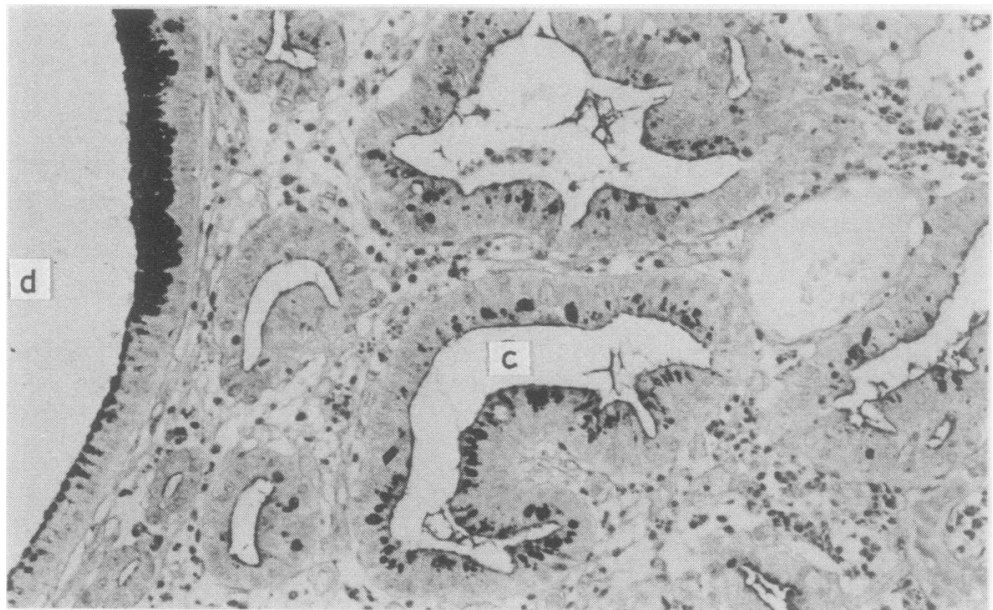

Fig. 10 Periodic acid Schiff (PAS) staining of the adenocarcinoma (same case as Fig. 9). A cystic duct (d) at the left is non-neoplastic. The other tubules are cancer tissues. The cancer cells (c), like the normal foveolar cells, have surface coat mucin, and contain PAS positive mucin droplets. The mucins do not stain with alcian blue and high iron diamine. $\times 200$ 


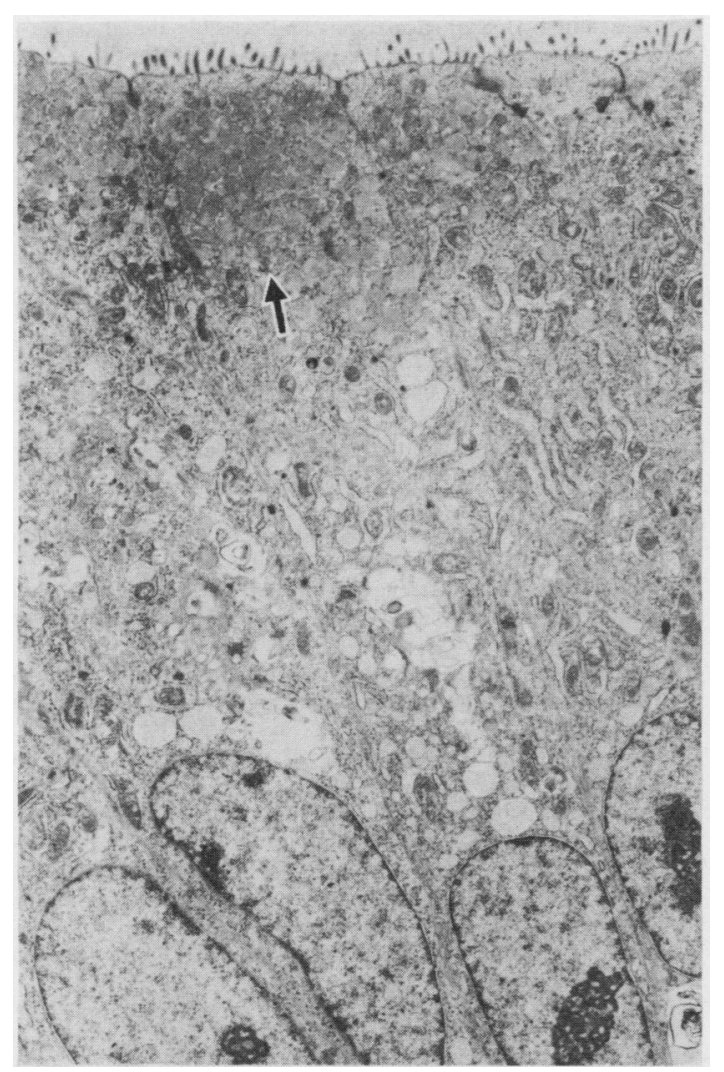

Fig. 11 Electron micrograph of the adenocarcinoma (same case as Fig. 9). The cancer cells are well polarised columnar cells, containing mucigen granules oflow electron density (arrow). Formalin fixation. Original magnification $\times 6800$.

\section{Intestinal type adenocarcinoma}

In one polyp (from a 55 year old man) we found an intestinal type adenocarcinoma. The cancer tissue consisted of tubular structures, resembling those adenocarcinomas commonly seen in the stomachs of older patients. The cancer cells were columnar cells, containing large nuclei and eosinophilic cytoplasm. A few mucin containing cells, similar to goblet cells, were also found. The cancer cells had surface coat mucin, composed of sulphomucin, which stained with alcian blue and high iron diamine. The mucin in goblet cells was also sulphomucin.

\section{Discussion}

Hyperplastic polyps of the stomach have no counterpart in other parts of the gastrointestinal tract and are thereby organotypical. ${ }^{4}$ No comparison is possible with the adenomatous polyp in the colon. The main importance of polyps lies in their possible premalignant nature. There is, however, no agreement with regard to the premalignant properties of the hyperplastic polyp in the stomach. To evaluate the primary occurrence of malignancy in and associated with the hyperplastic polyp, circumstantial morphological evidence linking them to gastric carcinomas is needed.

Although more than half of the polyps were composed of cells completely identical to the normal gastric cells, nearly half $(47 \%)$ of the polyps contained other cytological elements. One atypical element was the presence of intestinal type cells. This must reflect intestinal metaplasia of the polyps.' The occurrence of the intestinal metaplasia was only local, however, and the metaplasia was incomplete. ${ }^{18}$ Tubules within the polyp become involved in intestinal metaplasia less often than tubules outside the polyp. ${ }^{16}$ In this study we found two cases of intestinal dysplasia and one case of intestinal type adenocarcinoma. These lesions appear to be a change related to intestinal metaplasia, similar to the case in the gastric mucosa without polyps. ${ }^{411^{13}}$ It must be emphasised, however, that intestinal type neoplasias occur uncommonly in hyperplastic polyps.

More commonly, we encountered gastric type neoplasias in the hyperplastic polyps. We found nine cases of dysplasia other than the intestinal type. The dysplastic cells showed exclusively gastric characteristics. The cancer cells closely resembled the normal foveolar cells and contained neutral mucin. No intestinal characteristics were found in the cells. The adenocarcinomas were therefore of a gastric type, and the adenocarcinomas and the dysplasias were related. They might result from atypical foveolar hyperplasia occurring in the polyps. ${ }^{16}$

In this study the incidence of adenocarcinomas was $3 / 67$. This value is similar to that reported by Laxen et $\mathrm{l}^{4}$ and Tomasulo5; carcinomas were seen in $2-6 \%$ of patients with polyps other than the adenomatous ones. In previous studies ${ }^{720}$ carcinomas arising in hyperplastic polyps have often been described as polyp carcinoma. Most of them were papillary and tubular adenocarcinomas. Accordingly, these have been considered as intestinal type cancers, but a detailed study of gastric or intestinal type features has not been performed..$^{780}$ Some of the previously described polyp carcinomas may well include gastric type adenocarcinoma.

From a histogenetic point of view, gastric cancers have been classified into two main histological types: a diffuse type and an intestinal type. ${ }^{921}$ The former tends to occur in young patients. No precursor lesion has been identified for this type. ${ }^{22}$ The latter is prone to arise in the gastric mucosa with intestinal meta- 
plasia of old patients. 120

Other cancers include adenoacanthomas, carcinomas simplex, and undifferentiated carcinomas. ${ }^{1120}$ These cancers are rare, and their histogenesis has not been fully elucidated.

In addition, it remains uncertain whether or not there is any other adenocarcinoma other than the intestinal type, and whether or not carcinomas arising in the stomach without intestinal metaplasia are exclusively of a diffuse type. In the present study only gastric type adenocarcinoma was represented.

Gastric type adenocarcinomas may arise in the gastric mucosa lacking hyperplastic polyps, when foveolar hyperplasia takes place. ${ }^{23}$ Stump carcinomas in humans ${ }^{24} 25$ and gastric adenocarcinomas in animals induced by chemical carcinogens ${ }^{26-28}$ (in which intestinal characteristics are rarely seen) might also represent gastric type neoplasias. In these cancers foveolar hyperplasia rather than intestinal metaplasia may be the lesion predisposing to the development of carcinomas..$^{24-28}$

This study was supported by a Grant-in-Aid for Cancer Research from the Ministry of Education, Science and Culture, Japan.

\section{References}

' Elster K. Histologic classification of gastric polyps. In: Morson BC, ed. Pathology of the gastrointestinal tract. Current topics in pathology, vol 63. Berlin: Springer-Verlag, 1976, 77-93.

2 Johansen A. Elevated early gastric carcinoma. Differential diagnosis as regards adenomatous polyps. Pathol Res Pract 1979;164:316-30.

${ }^{3}$ Ming S, Goldman H. Gastric polyps. A histogenetic classification and its relation to carcinoma. Cancer 1965;18:721-6.

${ }^{4}$ Laxen F, Sipponen P, Ihamaki T, Hakkiluoto A, Dortscheva Z. Gastric polyps; their morphological and endoscopical characteristics and relation to gastric carcinoma. Acta Pathol Microbiol Scand [A] 1982;90:221-8.

${ }_{5}^{5}$ Tomasulo J. Gastric polyps. Histologic types and their relationship to gastric carcinoma. Cancer 1971;27:1346-55.

- Kozuka S, Masamoto K, Suzuki S, Kubota K, Yokoyama Y. Histogenetic types and size of polypoid lesions in the stomach, with special reference to cancerous change. GANN 1977;68:267-74.

${ }^{7}$ Kamiya T, Morishita T, Asakura H, Munakata Y, Miura S, Tsuchiya M. Histoclinical long-standing follow-up study of hyperplastic polyps of the stomach. Am J Gastroenterol 1981;75:275-81.

${ }^{8}$ Nakamura T. Pathohistologische Einteilung der Magenpolypen mit spezifischer Betrachtung ihrer malignen Entartung. Chirurg 1970;41:122-30.
' Grundmann E. Histological types and possible initial stages in early gastric carcinoma. Beitr Pathol Anat 1975;154:256-80.

${ }^{10}$ Sugano H, Nakamura K, Takagi K. An atypical epithelium of the stomach. A clinico-pathological entity. GANN Monograph on Cancer Research 1971;11:257-69.

"Sugano H, Nakamura K, Kato Y. Pathological studies on human gastric cancer. Acta Pathol Jpn 1982;32:329-47.

${ }^{12}$ Schauer A, Kunze E. Relation of adenomatous hyperplasia of the gastric mucosa to carcinogenesis. Pathol Res Pract $1979 ; 164: 328-48$.

${ }^{13}$ Morson BC, Sobin LH, Grundmann E, Johansen A, Nagayo T, Serck-Hansen A. Precancerous conditions and epithelial dysplasia in the stomach. J Clin Pathol 1980;33:711-21.

${ }^{14} \mathrm{Lev}$ R. The mucin histochemistry of normal and neoplastic gastric mucosa. Lab Invest 1965; 14:1418-29.

is Spicer SS. Diamine methods for differentiating mucopolysaccharides histochemistry. J Histochem Cytochem 1965; 13:211-34.

16 Jass JR, Filipe MI. Sulphomucins and precancerous lesions of the human stomach. Histopathology 1980;4:271-9.

1 Rubin W, Ross LL, Sleisenger MH, Jeffries GH. The normal human gastric epithelia- A fine structural study. Lab Invest 1968; 19:598-626.

${ }^{18}$ Hattori T. Histological and autoradiographic study on development of group III lesions (dysplasia grade III) in the stomach. Pathol Res Pract (in press).

${ }^{19}$ Muto T, Oota K. Polypogenesis of gastric mucosa. GANN 1970;61:435-42.

${ }^{20}$ Remmele W, Kolb EF. Malignant transformation of hyperplasiogenic polyps of the stomach. Endoscopy 1978;10:63-5.

${ }^{21}$ Lauren P. The two histological main types of gastric carcinoma: diffuse and so-called intestinal type carcinoma. Acta Pathol Microbiol Scand [A] 1965;64:31-49.

${ }^{22}$ Correa P. Precursors of gastric and esophageal cancer. Cancer 1982;50:2554-65.

${ }^{23}$ Konjetzny GE. Der Magenkrebs. Stuttgart: Ferdinand Enke Verlag, 1938: 28.

${ }^{24}$ Saegesser F, James D. Cancer of the gastric stump after partial gastrectomy (Billroth II principle) for ulcer. Cancer 1972; 29:1150-9.

${ }^{25}$ Littler ER, Gleibermann E. Gastritis cystica polypora (gastric mucosal prolapse by gastroenterostomy site, with cystic and infiltrative epithelial hyperplasia). Cancer 1972;29:205-9.

${ }^{26}$ Kobori O, Gedigk P, Totovic V. Adenomatous changes and adenocarcinoma of glandular stomach in Wistar rats induced by $\mathrm{N}$-methyl-N' $\mathrm{N}^{\prime}$-nitro-N-nitrosoguanidine. Virchows Arch [Pathol Anat] 1977;373:37-54.

${ }^{27}$ Kunze E, Schauer M, Eder M, Seefeldt C. Early sequential lesions during development of experimental gastric cancer with reference to dysplasia. J Cancer Res Clin Oncol 1979;95:247-64.

${ }^{28}$ Hattori T, Helpap B, Gedigk P. Cell proliferation and growth of gastric carcinoma induced in inbred Wistar rats by $\mathrm{N}$ methyl-N'-nitro-N-nitrosoguanidine. Cancer Res 1984;44: 5266-72.

Requests for reprints to: Dr T Hattori, Department of Pathology, Fukui Medical School, Matsuoka Yoshida-gun Fukui, 910-11 Japan. 